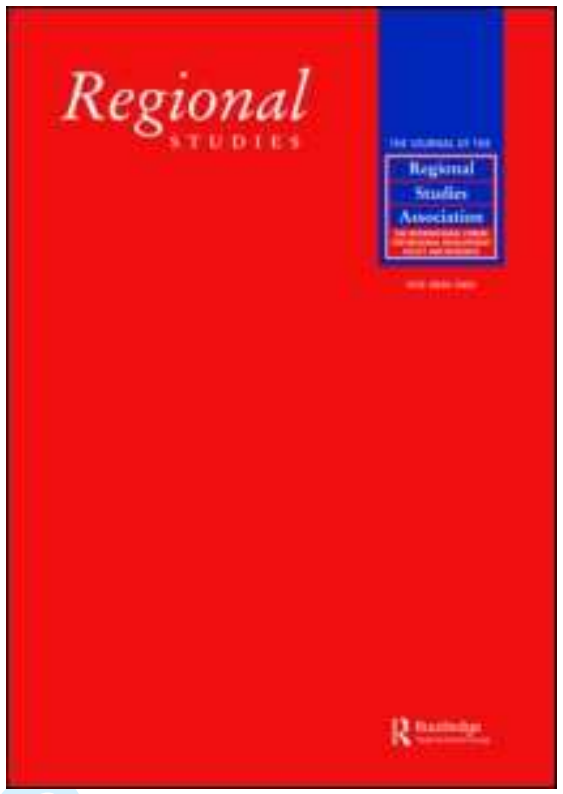

\title{
CLUSTER OR CAPTURE? MANUFACTURING FOREIGN DIRECT INVESTMENT EXTERNAL ECONOMIES AND AGGLOMERATION
}

\begin{tabular}{|c|l|}
\hline Journal: & Regional Studies \\
\hline Manuscript ID: & CRES-2006-0114.R2 \\
\hline Manuscript Type: & Main Section \\
\hline JEL codes: & $\begin{array}{l}\text { F23 - Multinational Firms } \mid \text { International Business }<\text { F2 - } \\
\text { International Factor Movements and International Business }<\text { F - } \\
\text { Organization, R11 - Regional Economic Activity: Growth, } \\
\text { Development, and Changes < R1 - General Regional Economics }<\text { R } \\
\text { - Urban, Rural, and Regional Economics }\end{array}$ \\
\hline Keywords: & $\begin{array}{l}\text { Industry clusters, multinational enterprise, foreign direct } \\
\text { investment, internalisation, externalities }\end{array}$ \\
\hline
\end{tabular}

\section{SCHOLARONE \\ Manuscripts}




\title{
CLUSTER OR CAPTURE? MANUFACTURING FOREIGN DIRECT INVESTMENT, EXTERNAL ECONOMIES AND AGGLOMERATION
}

\section{By}

\author{
N.A. Phelps, \\ Bartlett School of Planning, University College London, 22 Gordon Street, London \\ WC1H OQB
}




\begin{abstract}
This paper presents reviews the nature and significance of external economies associated with MNE participation in the manufacturing industries of host economies. It argues that the balance of forces of internalisation and externalisation is currently skewed towards the former and the interests of MNEs rather than the latter and the interests of local and national communities and governments. A stylised comparison of developmental and competition state interventions in relation to MNEs and their FDI suggests that in the absence of co-ordinated interventions by governments, there will commonly be a failure of the logic of internalisation to permit localised processes of externalisation. Indeed, the experiences of the 'competition states' of the UK and the USA, the potential for the partial internalisation or 'capture' of local institutions and collective consumption expenditures rather than the externalisation associated with clustering is highlighted.
\end{abstract}

JEL Classification: F23, F2, L52, R11.

Key words: Industry clusters, multinational enterprises (MNEs), foreign direct investment (FDI), internalisation, externalisation. 


\section{CLUSTER OR CAPTURE? MANUFACTURING FOREIGN DIRECT INVESTMENT, EXTERNAL ECONOMIES AND AGGLOMERATION}

\section{INTRODUCTION}

A series of criticisms of the economic development contributions of MNEs consistently levelled through much of the post war Fordist boom and into the early 1980s have given way to a new policy and academic orthodoxy that instead has highlighted the role of foreign direct investment (FDI) as a bearer of scarce capital and technology (Dunning, 1997). (1) These past concerns - of lack of local linkages and technology transfer, 'truncation' and the like - were developed in connection with manufacturing FDI and could be encapsulated in the widespread belief that FDI did not generate broader clusters but rather enclaves of economic activity (Kindleberger, 1969). The academic criticisms of MNEs were related to the policy community's specific concerns over failed attempts to create growth poles around FDI. Whilst the criticisms of MNEs and their associated FDI have not completely disappeared, there is now somewhat of an assumption in recent academic and policy literature that FDI almost inevitably delivers economic development benefits.(2) Indeed, the view that foreign ownership is bad for the development of industry clusters 'is a curious argument, in that there is currently very little academic support for it' (Birkinshaw, 2000: 96). In short, the new belief might be encapsulated in the thought that FDI can and does contribute to cluster formation. 
Are we to assume that these earlier concerns were unfounded? Or ought we, as I explain in this paper, to retain important critical insights and the sort of questioning policy stances implicit in such earlier literature in a contemporary reappraisal of the contribution of FDI to national and local economic development? It is ironic that such criticisms were voiced in a period of strong nation states with active industrial policies and unprecedented and sustained economic growth in developed countries and indeed many developing countries. Yet such concerns seem to have disappeared in a period of widespread and possibly cavalier opening and de-regulation of national economies and substantive disengagement of states from industrial policy in a context of comparatively slow economic growth. New policy prescriptions - such as the promotion of clusters often are over-generalised and rhetorical since they actually require the sorts of active policy interventions that rarely are now countenanced by governments, at least those in western 'competition states' (Cerny, 1997).

This paper focuses on the potential for manufacturing FDI to promote clusters of economic activity. The argument is that, in an increasingly internationally integrated and neoliberalising world economy, the economic benefits assumed to derive from FDI cannot be taken for granted. They remain to be obtained in the marrying of government policy with FDI motives. The continued need for government interventions - and an enhanced analytical base from which they can draw - is more important than ever. This is because of the fundamental tension between the logic of 'internalisation' that is the essence of the MNE and the 'externalisation' desired by states in order to produce wider 
benefits to society but also because of the asymmetries between the sophistication of MNE strategy and national and local government bargaining with MNEs.

The paper begins by first considering the equivocal benefits of manufacturing FDI due to the tension between internalisation and externalisation played out at the subnational scale in the form of clustering.(3) After noting that the external economies presumed to derive from clustering are the exception rather than the rule in instances of MNE-dominated clusters, the paper goes on to consider the opposite scenario - of capture or internalisation of important local and national resources by MNEs. The paper concludes by urging a more careful and critical appraisal of the benefits to be gained from manufacturing FDI and the sorts of policy interventions required to make these happen.

\section{MNEs, INTERNALISATION, EXTERNALISATION AND LOCAL ECONOMIC DEVELOPMENT}

The pioneering work of economists stressed the logic to internalisation that has driven the rise of MNEs (Hymer, 1976; Vernon, 1969). Subsequent work also stressed the coordination or transaction costs involved in exploiting ownership advantages overseas (Buckley and Casson, 1976; Dunning, 1979). Indeed the costs of coordinating production overseas are central to understanding the potential for externalisation or outsourcing and industrial upgrading within global production networks.(4) Notwithstanding these trends, the point I wish to develop in this section is that the logic of internalisation within MNEs 
is only rarely met by an equal force of states' attempts to coordinate the externalisation process and the generation of local economic benefits.

\section{Internalisation $^{2}$ versus externalisation}

In any analysis of the economic development implications of MNEs it is salutary to begin with what is commonly regarded as the fundamental insight. The essence of the MNE has been recognised as one of a desire to exploit firm-specific advantages across borders internally within the corporate entity. It is precisely this that prompted concerns of the substitution of international intra-firm sourcing for localised inter-firm linkages, associated transfer pricing manoeuvres, and the limited nature of technological spillovers. As Streeten notes

the packaged or complete nature of the contribution of the transnational enterprise usually claimed as its characteristic blessing is then the cause of the unequal international division of gains. If the package broke, or leaked, some of the rents and monopoly rewards would spillover into the host country. But if it is secured tightly, only the least scarce and weakest factor in the host country derives a limited income from the operations of the transnational firm (Streeten, 1999: 52).

The process of international economic integration is, then, a contradictory one 'that necessarily produces, as its support, a space of flows and, as its nemesis, the importance of place, a place of objective and subjective resistance' (Jessop, 1999: 37). For a number of inter-related reasons, this opposition between internalisation or the space of flows on the one hand and externalisation and the space of places on the other is asymmetrical and becoming increasingly so in today's policy environment. The logic of internalisation is at 
least an order of magnitude greater than the logic of local (i.e. sub-national) externalisation. Some of these asymmetries are illustrated in this section which contrasts the relative absence of state interventions surrounding manufacturing FDI in the competition states of the UK and USA when compared to the more interventionist stances adopted in Northeast and some Southeast Asian states. The key features of this contrast as described below are highlighted in figures 1 and 2.

\title{
INSERT FIGURES 1 AND 2 ABOUT HERE
}

\begin{abstract}
First, firms, and MNEs perhaps more so, posses a degree of structural power in relation to governments (Lindblom, 1977). They are able to reduce their goals to a single common denominator - money - unlike states, which have competing constituencies and hence policy objectives to balance (Boddewyn, 1993). As a consequence, in figures 1 and 2, the coordinative links between parts of the MNE are generally stronger than those emanating from state bodies.
\end{abstract}

Second, if we agree that the essence of the modern corporation is a single centre of control (Cowling and Sugden, 1998), then there are always and everywhere two tiers of internalisation processes at play in MNEs in many industry sectors: the internalisation embodied at the level of individual subsidiaries in diverse locations and the internalisation or coordination among a group of subsidiaries exerted by parent company headquarters. (5) The same can only infrequently (in the case of successful Northeast Asian developmental states) be said in the case of local and central governmental 
institutions within nations. Widespread liberalisation, withdrawal from intervention and the difficulties of maintaining territorial integrity mean that central governments fail to exert the sort of co-ordinating role among their subsidiary institutions necessary to ensure processes of externalisation and hence industry cluster formation associated with FDI. There may also be disarticulation among, and even dysfunctional behaviours of, subnational government and quasi-governmental bodies. Moreover, the developmental states of Northeast Asia stand in contrast to the competition states of the UK and USA in their desire to coordinate the competitive capacities of indigenous enterprise and its interactions with the foreign owned sector. In this connection, the specific policy interventions that may be required to promote industrial clusters may pose additional problems due to the inverse relationship between policy credibility and specificity that is hypothesised to exist (Murtha and Lenway, 1994). Some sense of these differences in the coordinative capacity of states is illustrated in figures 1 and 2 which stylistically contrast the competition and developmental state models. The key differences between figures 1 and 2 centre on: (i) the overall density of coordinative links emanating from governmental institutions in the host country; (ii) the density of coordinative links between central and decentralised governmental bodies; and the density of coordinating links between governmental bodies and (iii) indigenous and (iv) foreign enterprise; and (v) the extent to which these coordinating links are consistently reinforced by different arms of government. In the MNE-competition state relationship depicted in figure 1, the lack of these coordinative links means that where clusters do develop they are likely to be of the 'contingent' or production-complex variety discussed later in the paper. The logic 
of internalisation associated with the FDI of MNEs is matched by the coordinative capacities of developmental states to produce viable clusters as depicted in figure 2.

Third, the asymmetry between the logics of internalisation and externalisation is actually greater than represented in figure 1 when we remind ourselves that MNEs' formidable competencies in coordinating activities are international in scope whereas states rarely are able to exert such a coordinative role within their national territories let alone internationally. This again is visible in figures 1 and 2. The emphasis in both figures is upon the host economy partly because coordinating links from host government bodies rarely extend overseas.

Fourth, we might add, à la Williamson (1975), that MNEs add opportunism or business/political strategy to the economic logic of internalisation. That is, not only are they in the business of protecting or internalising their ownership advantages but they also internalise with opportunism - they are open to opportunities to capture or internalise the competitive advantages represented by localised external economies where possible.(6)

Fifth, and finally, these specific asymmetries in the bargaining position of states and MNEs appear to have become accentuated by recent developments in the international economic and institutional environment (Stopford and Strange, 1991). The widespread liberalisation of FDI policies, the ceding of certain powers and competencies by nation states to supranational bodies has diluted the bargaining power of states - especially 
developing country governments - in what could be regarded as a two-tier bargaining process (Ramamurti, 2000). This increasingly asymmetrical bargaining position may well have contributed to a reduction in the economic development effects of FDI. As Buckley and Ghauri note 'Increasing locational "tournaments" to attract FDI ... may have reduced the benefits to the host countries as have the increasing skill of the managers of MNEs in making their investments more "footloose". Corresponding strategy on the part of host countries to make FDI "sticky" are not developing at the same rate' (Buckley and Ghauri 2004: 84). What this uneven bargaining position highlights is the very real potential for corporate capture of national and local institutions and resources which I go on to consider in the penultimate section of the paper.

\section{Externalisation and clustering}

While 'establishing viable clusters - of subcontractors and suppliers - around an important principal plant has been fashionable. ... analysis, and the impact of ecommerce, suggests that these clusters are becoming increasingly dispersed and virtual' (Buckley, 2004: 30). So, for example, some of the ingredients of the pure or Marshallian agglomerative forms have become available over extended - even global - geographic scales (Phelps, 2004a; Phelps and Ozawa, 2003). Moreover, recent work on global production networks indicates that even those Marshallian ingredients thought to be most geographically immobile are now subject to international patterns of diffusion. As Ernst et al (2001: 137) have recently argued, 'the most important caveat to the agglomeration economies argument is that dispersion is no longer restricted to low-end activities'. 
Theoretical understanding of agglomeration and clustering has been developed inductively from successful instances of industry clusters (Phelps, 1992; Phelps and Ozawa, 2003). Moreover, within this tradition, the question of the origins of such clusters is one that rarely has been addressed directly. As such, the theory of agglomeration or clustering is often circular in nature (Phelps, 1992), resting on positive or negative processes of cumulative causation derived from within the agglomeration or cluster itself, and with instances of agglomeration being taken as evidence of the existence of localised external economies and localised external economies being used to explain the existence of agglomeration. Something of this circularity is evident in that work which has explored the relationship of FDI to clustering processes - much of which is framed from the perspective of the contribution FDI makes to existing clusters. The literature that has dealt with FDI as an instigator of potential clustering processes, perhaps understandably, has remained obscure - focusing on the likes of failed attempts to produce growth poles or industrial complexes from scratch through FDI.

Something of this circularity is also apparent in the fact that, 'studies corroborate the hypothesis that developing countries must have reached a minimum level of economic development before they can capture the growth enhancing effects of FDI' (Nunnenkamp, 2004: 669). This also applies when we are concerned with localities within nations such that industrial clusters cannot develop without these preconditions being met (Enright, 1999). Certainly, the geographic concentration of FDI at a global scale reflects the entrenched favourable conditions in developed nations. (7) Until very 
recently, many developed nation economies could indeed rely on the externalities associated with this inertia in MNE organisation and patterns of FDI. In fact, until the 1980s, MNEs actually reinforced the economic cohesiveness of national territories (Agnew, 2005; Kobrin, 2000) when operating multi-domestic strategies under which there was a 'duplication of the value chain across countries, and local outsourcing' (Young, 2000: 5). There are now signs in certain economies - such as the UK and the USA - that, as the global production networks of MNEs continue to expand and become more complex, it cannot be assumed that external economies will flow in quite the same way. In-line with this reasoning, it is clear that 'the development of a national economy is more about internal integration than external integration', however, the new world agenda makes it more difficult to 'capture the synergies between internal and external integration' (Wade, 2003: 635 and 636). Thus the national investment development path (IDP) that can be stimulated by FDI (Dunning, 1981) depends on more than merely the upgrading of MNE affiliates in isolation. In intermediate stages of the IDP, government policy to enhance the locational and ownership advantages of domestic industry is vital to stimulating linkages with the FDI sector (Scott-Kennel and Enderwick, 2005). (8) In short 'even in a world of capital mobility, there is still a virtuous circle between activist government and international openness' (Garrett, 1998: 789). The internal integrity - and in particular a diverse, robust and competitive indigenous set of industries - of a national and local economy is important because in its absence the economic benefits of FDI essentially may circulate among the foreign-owned sector producing externality effects somewhat less than we commonly regard as agglomeration or clustering proper. 
In fact, 'if there has been relatively little research on the contribution that clusters make to MNEs, there has been even less on the contribution that MNEs make to clusters' (Enright, 2000: 118). Partly because of the opposing economic logics of internalisation and externalisaton noted above, much of the literature on the economic impacts of FDI has been framed in terms of binary scenarios which have proved hard to escape. These are apparent in the recent literature focused specifically on the contribution of FDI to industrial clusters. So, for example,

foreign firms may add to the local cluster by bringing in valuable capabilities and resources such as new knowledge and technology, capital, expatriates and other inputs ... However, the entry of foreign firms may also erode the basis of future cluster dynamics by "taking out" resources and competencies from the cluster. This may be done either by actively transferring resources from one subsidiary/cluster to another, or more indirectly by not making continuous investment in the build-up of the competencies and resources of the local unit (Malmberg and Solvell, 2002: 72).

There is evidence that while the type of industry cluster is important to understanding the capabilities and characteristics of MNE subsidiaries, industry clusters with high levels of foreign ownership have subsidiaries with less autonomy and weaker capabilities (Birkinshaw and Hood, 2000: 150). These findings are amplified by others from the UK that indicate that spillovers from FDI tend only to be associated with FDI into existing clusters founded on indigenous industry and are much reduced or even negative in new FDI-led clusters (De Propis and Driffield, 2006).

Following on from these findings, and as implied by the reference to the "taking out" of resources and competencies in the quotation above, there may, by the same token, be 
important instances of capture of local institutions and resources (Phelps, 2000). Indeed, in light of much of the policy advocacy surrounding FDI and in light of the retreat of many states from active intervention, there is a strand of thought that suggests that incentives have come to be viewed as compensation for the spillovers generated by MNEs (Li, 2005). This is a curious line of argument either in analytical or in policy terms, since the wider economic benefits in the form of externalities constitute a major argument for liberalisation of world trade and investment and ought not to need financial incentives from governments. In fact, as both neoclassical economics (Tiebout, 1956) and Marxian political-economy (Castells, 1982) stresses, some of the external economies most vital to the reproduction of private enterprise - such as communications infrastructure, education and welfare provision - have been provided by the state. Why should there be an expectation that states should underpin private enterprise through expenditures for 'collective consumption' while also having to pay for any private sectorgenerated externalities in the form of incentives for FDI? Moreover, the 'splintering' (Graham and Marvin, 2000) of such state-provided urban externalities may have opened up policy vacuums in which there is potential for the customisation or capture of expenditures intended for collective consumption.

The point I want to draw out from this part of the discussion is simply that the significance and sustainability of the sorts of clusters associated with manufacturing FDI remain open to question. As one recent review notes, 'If country and industry differences are important to the impact of inward FDI on host countries, the main lesson might be that the search for universal relationships is futile' (Lipsey and Sjoholm, 2005: 40). 


\section{MNEs, externalisation and types of clustering}

Of more immediate concern at this point in the argument is to establish the point that there are different types of clustering process to which FDI may or may not contribute. In a recent review of the literature, Gordon and McCann (2000) draw attention to three types of clustering: (i) the pure or Marshallian agglomeration, (ii) industrial complexes and co-location, and (iii) social networks. While the contribution of MNEs to each of these clustering processes is not an explicit element in their review, a major purpose of their work is to highlight the different logics and generative effects of clustering. Here they note then that 'discussion of industrial clustering has tended to conflate ideas arising from quite different perspectives ... The effect can be to buttress a rather generalised notion of the benefits of clustering' (Gordon and McCann, 2000: 515). More to the point, as McCann and Mudambi have argued, 'the inter-firm spillover arguments implicit in the pure agglomeration and social network models of industrial clustering are largely not applicable to MNEs' (McCann and Mudambi, 2004:509). This is because the information internalisation logic favouring the MNE is largely inconsistent with either the externality argument, favouring pure agglomeration, or the inter-personal relations of the social network' (McCann and Mudambi, 2005: 1871). This is particularly the case for MNE establishments that are part of oligopolistic industry structures (McCann and Mudambi, 2005: 1871)

http://mc.manuscriptcentral.com/cres Email: regional.studies@fm.ru.nl 
None of this is to deny a degree of permeability of the highly self-contained nature of MNEs - their FDI and other arm's length economic development effects they have - that has come to light recently. There is evidence to suggest that firm-specific advantages are increasingly produced not just from sources internal to the MNE but also from without, through its alliances with other MNEs, local institutions such as universities and technical institutes and associated pools of highly skilled labour (Dunning, 1997; Cantwell, 1995; Rugman and D’Cruz, 1997). More importantly still, recent sourcing strategies in some sectors have seen the stretching of the division of labour internal and external to MNEs and the re-emergence of an old principle of 'triangulation' responsible historically for the growth of new collections of industry on the back of old ones (Jacobs, 1969). The principle of triangulation and spillovers manifested through new arms length relations with independent suppliers in emerging market locations in the 'buyer-driven' global production chains of the food, clothing, textiles and footwear sectors do appear to have contributed to economic development in some Southeast Asian (Gereffi, 1999) and Latin American countries (Bair and Gereffi, 2000) though not in African nations (Gibbon and Ponte, 2005). Indeed, retail MNEs may be further distinguished by their high degree of localisation (Coe and Lee, 2005) or host nation 'territorial embeddedness', by virtue of responsiveness to cultures of consumption, the necessity to engage with local planning and property markets and the competitive advantages embodied in extensive logistical and supply chain activities (Wrigley, Coe and Currah, 2005). (9)

Greater local engagement by MNEs and the principle of triangulation may indeed be apparent in the genesis of clusters of industrial activity and associated wider economic 
benefits - though the question remains, what type of clusters are generated? In what follows, the case of 'contingent clustering' in Southeast Asia is instructive for the argument of this paper and is one that resonates in FDI-dominated regions in western 'competition state' nations such as the UK and the USA. The point being that, in the main, though not exclusively, manufacturing FDI contributes to variations on the production complex model of clustering distinguished by Gordon and McCann (2000).

Despite the rise of East Asia as a destination not only for Japanese but also European and North American FDI, the evidence regarding the precise contribution of FDI to economic development via clustering is open to question. Global production network analysis has highlighted the opportunities for industrial upgrading in certain developing countries as part of the process of triangulation. As developed country MNEs externalise and offshore production to a 'first-tier' of developing countries, production cost savings are made partly at the expense of increased co-ordination costs. It is these increased co-ordination or transaction costs that signal the leakage of otherwise internalised MNE capabilities and hence the build up of external economies - to developing country producers who then in turn further outsource and externalise production to a third set of countries and producers. However, different phases of MNE expansion in East Asia may have offered distinctly different, and on the whole diminishing, possibilities for local industry cluster formation from the 'triangulation' of trade within global production networks as Felker $(2003,2004)$ has detailed. 
The industrialisation of Northeast Asian developing countries such as South Korea and Taiwan began in the 1950s and 1960s - a very different era of MNE expansion in which the character of FDI did indeed interact with domestic industry to promote what Cantwell (1988) refers to as a virtuous circle of industry development. Nevertheless, such success stories are also based on a congruence of conditions that (a) have involved 'developmental state' intervention and (b) have taken decades to mature. As Ernst argues

interorganizational knowledge creation is not confined to regional clusters or to the nation state. In industrialized countries, many of these external knowledge linkages are within domestic organizations. This is very different from a small developing country ... [where] benefits from international linkages do not come automatically. Of critical importance are government policies that have created a set of innovative institutions and incentives conducive for interorganizational knowledge creation (Ernst, 2001: 125-126 original emphasis).

As the case of the Taiwanese electronics and computer industry illustrates, foreign enterprise can indeed play an important role in cluster development but is just one of at least four elements including the parallel government support of the indigenous sector (Ernst, 2001).

In a recent article charting the growth of a new high technology cluster in Beijing, China centred on the arrival of Finnish telecommunications company Nokia, Yeung, Liu and Dicken are actually more specific in identifying these international knowledge flows that are possible in global production networks. They term such flows 'non-cluster economies' whose 'realizaton ... is not necessarily an outcome of proximity per se, but rather a product of relational networks that ... allow [firms] to tap into external economies outside ... clusters' (Yeung, Liu and Dicken, 2006: 521, original emphasis). 
Their interest here is in demonstrating the role of a lead FDI project in leveraging knowledge assets in existing clusters to initiate the formation of a new cluster. Their study is instructive in pinpointing the origins of new clusters in developing countries but they are right to leave the question of the longer-term sustainability of such new clusters as an open one. As McCann and Mudambi (2005: 1871) stress, 'many industrial clusters which include large oligopolistic competitors will generally be plagued by adverse selection and should either fail to form, or become concentrations of mediocrity'. What Yeung, Liu and Dicken's study confirms is that 'as developing countries are scrambling to develop industrial clusters, much more policy attention needs to be paid to how preconditions in specific localities in these countries can interact with the strategic requirements of lead firms and their key suppliers in global production networks' (Yeung, Liu and Dicken, 2006: 537). The interesting point regarding China's FDI-led industrialisation is whether the preconditions represented by the sheer scale and diversity within the stock of human capital and indigenous business present more favourable initial conditions for sustaining significant new clusters than is perhaps the case in Southeast Asian countries as I now consider below.

It is the likes of Taiwan and South Korea (and Hong Kong) that developed sufficient domestic industry capabilities to act as first-tier loci of coordination from which global production networks can be further articulated with a 'second-tier' of lower cost locations. With the exception of Singapore, the upgrading dynamics among those (principally Southeast Asian) developing country clusters that now constitute the 'second tier' of processes of triangulation are less clear. Industrialisation took place in the 1980s 
and 1990s in which MNE strategies and organisational structures had evolved significantly. Although producing some clustering effects at least partly as a result of government industry policies these have not been based on localised factors. Thus, the 'industrial supply linkages, based on the "flying geese" model ... find modern expression as "growth triangles" operating in Southeast Asia. This relative lack of industrial diversity ... and hence the "thinness" of ASEAN's capital asset structure poses problems for the region ... (Bartels, 2004: 86).

Some sense of this thinness or lack of industrial diversity is also identified by Felker. More specifically still, then,

FDI clustering in Southeast Asia did not correspond to Porter's (1990) competitive "diamond", with a full set of vertical links to supplier and user industries, or to the collections of complementary assemblers, designers and component makers that define innovative SME clusters in the literature on Europe. Rather they were horizontal groupings of foreign manufacturers performing similar production functions, lured by suitable cost and infrastructure factors and, significantly, by the externalities (skills, knowledge, logistics infrastructure) generated by each other's presence (Felker, 2004: 88).

As such,

The key dynamic in Southeast Asia's MNE-based industrialisation ... might be termed "contingent clustering", in that there were relatively few territorially generated assets that could explain the dynamism of the foreign production establishment. Rather it was the co-ordination economies arising from MNCs investment decisions which gave rise to localised externalities among firms whose origins and primary linkages were non-local. ... What is distinct about this pattern is that it is "local" only in a very abstract sense (Felker, 2003: 267). 
Whilst some localised labour-market and even knowledge externalities are produced, due to the lack of a viable domestic industrial base, these are produced by and shared almost exclusively among the foreign-owned sector in these clusters (as depicted in the exclusively overseas MNE presence in the contingent cluster in figure 1). Moreover, following Aitken and Harrison (1999) the possibility that the positive externalities generated by FDI in host economies can be offset to a greater or lesser extent by negative externality effects associated with the crowding-out of indigenous industry has been recognised. The interesting point here is that these production-complex type clusters are potentially mobile in their entirety. Even Singapore, the exception among Southeast Asian experiences of industrialisation, has cycled through several such contingent clusters (Mirza, 1986) - the implication being that such ostensibly FDI-only clusters are only weakly embedded and capable of being migrated as and when conditions become propitious as has been the case over the past decade with re-location to China.

The second tier of triangular processes of industrialisation in the likes of Southeast Asia and mainland China has often been directly or indirectly orchestrated (Ernst, 2001) by the states or leading firms of first tier developing countries through the development of overseas enclave industrial parks (Pereira, 2003; Perry and Yeoh, 1999 and Yeung, 1999 on the case of Singapore). The simplest forms of clustering involving Export Processing Zones and the industrial parks that constitute elements of the triangulation of production in Southeast Asia generate few backward linkages and minimal externalities through labour market interactions. Labour market mechanisms are perhaps the main way in which there is technology transfer from MNEs in clusters (Thompson, 2002: 886). Yet 
the self-contained nature of many industrial enclaves including their labour markets precludes wider processes of technology transfer (Phelps, 2004b). In the most extreme cases, the major use of migrant labour is a positive hindrance to the development of labour sills and the diffusion of technology to the local environment. A major weakness of clusters dominated by MNEs therefore centres on the low degree of technological spillovers involved (Altenburg and Meyer-Stamer, 1999: 1706). Some of the major indirect economic benefits produced from these clusters are restricted to induced multiplier effects - the circulation of disposable income in the local economy and the build up of consumer services.

Despite the renewed interest in the role of FDI in industry clusters noted above, one of the major reviews of recent years was able to suggest that 'within Europe there seem to be rather few examples of successful growth centres in which MNEs play a leading or active role' (Young, Hood and Peters, 1994: 662). Thus, concerns over the vulnerability of clusters of FDI have been evident in the UK. Scotland's 'Silicon Glen' has failed to mature into a robust and sustainable cluster of activity. Similarly the sorts of growth-pole production complexes that have formed around major FDI projects such as Nissan in the North East of England have prompted concern over an extension of the so-called branch plant syndrome from single plants to a collection of plants (Amin and Robbins, 1990). The potential vulnerability of these production complex-type agglomerations with limited wider linkages to domestic industry stands in contrast to the occasional example of more dynamic clustering effects associated with major MNEs (Glasmeier, 1988). 
Ireland repeatedly is cited as an example of successful FDI-led industrialisation and has been the subject of policy initiative informed by notions of industrial clustering. MNEs have a considerable presence in the electronics industry and in particular the microcomputer industry. However, despite the substantial employment in such sectors, even here the possibilities for the development of clusters around leading MNEs appears limited. In light of global conditions and in the context of the current logistical arrangements preferred by MNEs 'the suitability of a strategy of building integrated clusters around subsidiaries of MNEs in the microcomputer assembly industry may well become of theoretical interest only' (van Egeraat and Jacobson, 2005: 300). What van Egeraat and Jacobson demonstrate successfully here is that variations on 'just-in-time' logistical practices said to promote agglomeration in some instances (Mair, 1993) have evolved in other instances to promote only, what Felker terms, abstract forms of localisation. Such abstract forms of localisation resemble not the pure agglomeration or social networks model but variations on the production complex model of clustering distinguished by Gordon and McCann (2000).

\section{MNE POLITICAL BEHAVIOUR AND CAPTURE}

The political behaviour of MNEs has been analysed in terms not dissimilar to the "black box" of neoclassical economics (Encarnation and Wells, 1985) - a black box that could usefully be opened if we are to fully explore critically the possibilities for economic development from MNEs (Phelps and Fuller, 2000). Yet, if anything, an interest in the political behaviour of MNEs has waned somewhat recently. 'The topics of political risk 
and external environment analysis were significant ones in the 1970s and 1980s; understandable at a time when general attitudes to MNCs were antagonistic, and controls over FDI and MNC behaviour were widespread' (Young, 2000: 17). In analytical terms - though hardly of less salience in policy terms - an analysis of the political behaviour of MNEs and their subsidiaries is just as important at a time when there is little serious questioning of the behaviour MNEs by host governments. In fact, the shifting boundaries of the firm make externalities a potentially elusive benefit to local and regional economies while 'frequently too little attention is given to the motives that firms have to capture agglomeration benefits internally' (Perry, 2005: 75).

Political behaviour adds an element of strategy or opportunism to an already powerful economic logic to internalisation as MNEs seek to augment or generate ownership advantages. The "rules of the economic game are not simple "givens" but are often "takens", with significant implications for the nature of ownership advantages and internalization of external agents' (Boddewyn, 1988: 344). Two further observations should be made regarding the potential for capture. First, complete internalization or capture of state functions and expenditures by MNEs is rare. Semi- or quasiinternalisation is the norm regarding instances of capture (Boddewyn, 1988: 356). Second, the organisation and nature of MNE-state relations vary according to the issuearea (Brewer, 1992) in question, with distributional issues (such as incentives) being those most open to 'capture' since these are a matter for negotiation between individual MNEs and host states. (10) 


\section{Information asymmetries and governmental failures to coordinate externalisation}

We saw earlier the asymmetrical bargaining position between MNEs and states as an ingredient in the potentially reduced impact of FDI. These information asymmetries and coordination failures on the part of governments have become most obvious with respect to the largest discrete FDI projects but may be magnified in the case of attempts to develop industry clusters.

Some of the most salutary lessons regarding the vicious circle of policy disengagement and failure of FDI to generate presumed benefits come from western nations - especially the 'competition states' of the UK and USA - which illustrate the problems caused by an absence of state coordination. Since the 1920s, the UK government has consistently had a relatively liberal open policy toward inward and outward FDI (Bailey, Harte and Sugden, 1994). This has coexisted with a long-standing desire to diversify those regional economies subject to structural decline since the industrial revolution through the dispersal of mobile investment - ostensibly FDI in recent decades. However, UK regional policy was oriented towards the symptoms of regional decline not the causes (Morgan, 1997 cited in De Propis and Driffield, 2006: 278). Indeed, from its inception, UK regional policy was explicitly designed to ameliorate the agglomeration effects that had begun to operate in reverse with the structural decline of the UK's older industries. However, in doing so it also precluded the build-up of the positive effects associated with the creation of newer agglomerations. The UK government has not engaged in any serious monitoring of the effects of FDI and has intervened only modestly and, crucially, 
in an inconsistent manner since this time (Bailey, Harte and Sugden, 1994; Hodges, 1974). More recently, UK governments have concentrated on creating a favourable macroeconomic environment to encourage FDI as a modernising force while neglecting microeconomic or industrial policy interventions that might have secured longer-term development (Young and Hood, 2001). Ironically then,

UK industrial policy is based upon the ad hoc attraction of large scale, jobcreating inward investment to create short-term jobs in declining regions. There is no coherent strategy integrating sector targeting and economic development, at least at the central level, and government policy has artificially dispersed foreign companies, missing out on any clustering benefits (Loewendahl, 2001: 219).

Hence the failure of viable clusters of industry to develop as depicted the bottom left portion of figure 1 . The emphasis has been on minimising the transaction costs facing prospective investors with the UK being an easy point of entry but, by the same token, also an easy point of exit, for FDI within the European Union (Amoore, 1999). As a result, and with a very few industry exceptions, there has been little incentive for MNEs to locate their most technology-intensive FDI in the UK or for such FDI to become embedded in virtuous circles of agglomerative tendencies (Cantwell, 1988).

This lack of coordination manifests itself in the likes of: wasteful competition among 'regions' within the UK for FDI projects (Tewdwr-Jones and Phelps, 2001); conflicting objectives or interests of different state and quasi-state bodies within regions over a single FDI project (MacKinnon and Phelps, 2001); and even the complicity of national governments in eluding the European Commission's attempts to coordinate the likes of investment incentives rules and reporting (Thomas, 2000). More fundamentally, 
however, it is borne of a lack of consistent, concerted and credible national and local policy geared toward producing conditions conducive to garnering the important externalities associated with FDI as part of wider strategies to develop industry clusters (depicted as an absence of coordinative links between the state and industry in figure 1). A number of recent studies have highlighted the implications of the ad hoc attraction of FDI for local economic development and the potential for capture in the case of large discrete FDI projects. The information asymmetries between MNEs and governments are most apparent with respect to these sought-after investments since, whilst the requirements and financing of the investments are a closely guarded secret, the sorts of government assistance is invariably open to public scrutiny (Phelps, Lovering and Morgan, 1998; Phelps and Tewdwr-Jones, 1998). Drawing on a study of the Nissan and Siemens investments in the Northeast of England, Loewendahl (2000) concluded that the UK central government has rarely deployed the full power of its position when bargaining with MNEs at the time of initial entry. As a consequence, despite greater targeting of the financial incentives operated under UK regional policy since the 1960 s, it has now become synonymous with the attraction and dispersal of FDI (Driffield, 2004). A recent National Audit Office (NAO, 2003) report spoke of the 'grants culture' among the MNEs which now absorb the majority of regional policy incentives. Such a 'blanket approach to attracting manufacturing inward investment ... could be connected with the development of clusters of foreign activity which underperform' (Munday, Peel and Taylor, 2003: 519-520) and create few positive impacts beyond direct employment (Driffield, 2004: 592). 
The sorts of information asymmetries and coordination failures that exist on a case-bycase basis for discrete FDI projects are likely to be magnified when we examine the prospects for broader based policy interventions to stimulate industry clusters from FDI. Drawing on the sometimes chastening experiences with cluster development in Scotland, Peters and Hood make explicit the difficulties policy makers face: 'any local policy maker would require a very detailed understanding of all the key interrelationships in a cluster ... imperfections. This is rarely feasible. And, even if it were the public sector is seldom best placed to meet the need that key cluster stakeholders have for rich, industry specific information of an advanced and specialized nature' (Peters and Hood, 2000: 76).

In the USA, the degree of central (Federal) government co-ordination in the form of FDI policy is even less than in the EU (Graham, 2003). New 'entrepreneurial' state policies have not displaced old policies based on reducing factor costs to mobile capital while there is also a 'disjunction between sub-national and national economic strategy' (Eisinger, 1988: 5). Thus, Federal macroeconomic policy has served at times to weaken the bargaining positions of city and state governments, with anti-inflationary policies exacerbating local unemployment and hence the scramble for FDI - as was the case with new flows Japanese FDI into the United States during the 1980s (Lowery, 1990). At this time, any 'efforts by states to develop independent industrial policy have been less than entirely successful, or at least not as successful as they might have been. And ... the roots of this at least partial failure are to be found at the national level of government' (Lowery, 1990: 193). Reid and Gattrell's (2003) study highlights the information asymmetries that exist between one MNE and state and local governments in the 
bargaining process over the level of financial and other incentives necessary to keep Jeep's investment in-situ in Toledo. Wood (2003) has highlighted that information asymmetries have also contributed to the lack of clustering of related inward investments at an intra-metropolitan scale.

Again, the experiences of Southeast Asian states can prove instructive as to the magnitude of the policy effort required to successfully harness FDI to wider clusters in which there are significant and cumulative external economies operating. As we saw earlier, FDI-led production-complex type clusters have developed in Southeast Asian states. Although some instances of clustering such as Penang's concentration of high technology industries have been regarded as models of industrialisation (including in this case the development of localised linkages) (UNCTAD, 2002), the need for government coordination of industrial policy is also clear. Whilst not completely unsuccessful, state industrial policy has contributed to the particular character of these 'contingent' clusters. 'Compared to Singapore's disciplined and highly detailed efforts to foster specific FDI clusters, most of the region's policies suffered from haphazard implementation and poor bureaucratic coordination' (Felker, 2004: 91). As such, 'Southeast Asian host economies can rely less than before on the internal technological dynamism of foreign-dominated sectors to bring structural change. Instead cluster-building efforts depend more than ever on local factors, including the policy capacities of state investment and industrial extension agencies' (Felker, 2004: 95).

\section{MNEs and internalisation: two examples of capture}


In a context of hostile state-firm relations that existed through the 1950 s to 1980 s, MNE political behaviour was common place and focused on managing the political and economic risk of engaging in many host country regulatory environments (Vernon, 1971). In today's more liberalised environment, arguably MNE political behaviour may be just as pervasive although the objectives may have changed toward opportunistic strategies centred on capturing or internalising those externalities available in host countries (Phelps, 2000; Phelps and Fuller, 2000). In the remainder of this section I highlight the possibilities for MNE subsidiaries to partially capture collective consumption expenditures and local externalities associated with local land/property and labour markets.

\section{(i) The land nexus}

In the western competition states of the UK and USA at least, land, property and physical infrastructure (such as roads and power generation) have become an important ingredient in the capture of local institutions by major corporations (Monbiot, 2001) including MNEs. Using the case of Nissan in the Northeast of England, Peck (1996) describes a longer term shift in the planned collective provision of infrastructure for inward investors in the UK toward an increasingly customised provision for individual inward investors by the 1980s. Since this time, the pattern of customised provision of infrastructure with its associated opportunity costs has been repeated with major FDI projects such as Toyota, LG, and Siemens in the UK (Phelps and Tewdwr-Jones, 2000). In the United States too, 
such land deals and their financing as part of broader incentives packages have proved controversial (Yanarella and Green, 1990).

The customised assembly of land and provision of property and infrastructure raises many important questions. For a start there are questions regarding democratic accountability and due process since land-use and planning policy can and has been ignored on the basis of the economic arguments in favour of developments. Critically, the environmental impacts of FDI typically receive less of an airing than economic development issues (Yanarella and Green, 1990). The sustainability of, and opportunity costs associated with, the use of often large tracts of prime green or even industrial land for investments that have a dwindling life expectancy is also of significance. The ill-fated LG investment in Wales, for example, took up a golden strategic site and effectively curtailed key planning and land use options locally (Phelps and Tewdwr-Jones, 1998) despite never being more than half realised as a project and closing within 6 years. Moreover, the 'planning gain' that local governments are commonly allowed to bargain for with major developments has rarely been obtained in the case of FDI projects. Not one of the largest ten FDI projects into Wales during the 1980s and 1990s had generated planning gain for the municipalities involved (Alden, 1999). If anything the opposite has tended to occur, with improvements to road access or power supply being paid for by the municipal or decentralised arm of central government as part of an incentives package. The customisation of space can also extend to the land and infrastructure requirements associated with assembling the limited, 'abstract' production complex externalities in the form of supplier-parks for major FDI projects (Phelps and Fuller, 2001). 
In the East Asian developmental states the participation of overseas companies in land and property market speculation and the distortion of planning priorities may be less prevalent due to widespread state ownership of land and various restrictions on land ownership and usage.(11) Indeed, in the least developed country settings it is private enterprise including FDI that sometimes individually or collectively provides important elements of infrastructure such as roads and power generation or telecommunications in the absence of state capacity to fund such collective consumption expenditures (Fisiman and Khanna, 2004).

\section{(ii) The labour-market nexus}

Conceivably, those externalities bound up with the labour market are those that MNEs have the most difficulty in preventing leaking into the local economy even in developing nations. In the competition states of the UK and the USA where they can, MNEs have preferred not to cluster their major FDI projects alongside other major investors but to locate away from each other so as to exercise a degree of domination over local labour markets and avoid competition for labour. In the context of skills shortages in advanced economies there may be a further twist in a quite familiar story.

The impact of manufacturing FDI in generating externalities via the local labour markets may not be as strong as presumed. First, the training of workers often now constitutes part of the customised package of incentives offered to a new major FDI project. Second, 
there is a case for arguing that high technology FDI, regardless of its longevity, can exert a positive effect on local labour force skills (Charles and Benneworth, 1999). However, Dawley's (2007) work on the labour market 'imprints' of major FDI semiconductor projects in the northeast of England highlights how the pressure for fast 'ramp-up' of production can translate into 'off-the-shelf' labour forces, a significant proportion of which have been recruited from existing employers outside the locality. Third, in light of increased personal mobility and as a result of the first two developments noted above, an important proportion of new skills added to the local workforce are lost at or before closure. The potentially positive role of FDI and associated skills within new rounds of investment - in Massey's (1984) terms - may be less than was the case in the past. The combination of these effects means that an important element of the sunk costs associated with the set-up of an operation - the sort of private investments that might keep an MNE establishment rooted to a particular place are off-set by public expenditures. The net effect of this may be to further shorten the lives of MNE subsidiary operations and increase the turnover of FDI in the local economy.

At local level, skills agendas are now routinely distorted by major FDI projects at their arrival. Where there is a lack of wider business community involvement in education and training agendas in localities whose economies are dominated by FDI, major MNEs can exert disproportionate influence. In some contexts - notably the smaller national or regional economies of the UK dominated by FDI - it has been a near permanent feature of the policy environment with both established investors, such as Ford, Sony and BAe Systems (Phelps, Valler and Wood, 2005), and new investors, such as LG (Phelps, 
Lovering and Morgan 1998), able to tilt local education and training strategies towards their specific needs.

In actual fact, one ought not to press the case for capture too far in the case of education and training agendas. MNEs have been important agents in the modernisation of labour market skills in places like Wales (Rees and Thomas, 1994). Moreover, Phelps and Fuller (2001) and Phelps, Valler and Wood (2005) illustrate that whilst there is customisation in the training and education policy sphere in a nation such as Wales, this has been associated with a countermovement by which policy-makers have been relatively successful in broadening these developments to the wider population of foreign and indigenous companies.

Whilst at international and national scales there is evidence to suggest that MNEs have become sensitised to the possibilities for tapping into sources of highly skilled labour and created assets (Cantwell, 1995; Dunning, 1997) it is incorrect to assume that the presumed benefits will accrue at the subnational scale in the form of the clustering of research and development and design activities of MNEs. As McCann and Mudambi (2005: 1871) argue instead, 'many of the largest firms do not co-locate their knowledgecreation activities with those of their competitive rivals ... Moreover, in situations in which they do so, the organisational aspects of the firms are designed specifically to avoid the sharing of knowledge'. Rather, there are concerns over the so-called 'reverse spillovers' responsible for the undermining of host economy technological capacities as a result of such technology sourcing by MNEs (De Propis and Driffield, 2006: 279). 


\section{CONCLUSION}

In the title of this paper I have opposed two scenarios of industrial clustering and capture. Binary oppositions have proved extremely hard to transcend in the literature on FDI and economic development, and the intention here is not to add a further binary to our lexicon. Instead, the title is intended to be rhetorical only - a device to draw attention to the role for government intervention in the extraction of economic development impacts from MNEs and their FDI in ways that over time may come to constitute what we regard as (Marshallian) clustering proper.

It is ironic that those policy and academic discourses most critical of the economic impacts of FDI appeared at a time when, by and large, benefits could be assumed to flow 'automatically' from FDI as a result of openness to trade and investment flows without government intervention. A further irony here is that it seems likely that instances of inappropriate government interventions both in developed nations such as the UK and certain groups of developing nations such as those in Latin America, actually prevented the fuller realisation of these 'automatic' benefits of FDI. Yet, at a time after qualitative changes in the MNE-orchestrated organisation of production, widespread liberalisation and the hollowing-out of many nation states (such that these benefits can no longer be assumed to flow), both academic and policy discourses have, to a significant extent, retreated from a critical interrogation of the precise contribution of FDI to clustering processes and economic development. Whilst new clusters of FDI dominated activity 
have become visible in developing countries they also serve as a potent reminder to developed nations of the value of intervention in capturing the now relatively modest and 'contingent' economic impacts that are on offer in any one location in the form of clustering. More broadly then, 'removing obstacles to operations by foreign investors without going overboard in favouring them is the challenge that faces those who regulate FDI today' (Mody, 2004: 1210).

However, inward investment policy is not enough since 'only by concentrating resources sectorally, technologically and spatially would it be possible to come close to creating conducive conditions for cluster generation' (Young, Hood and Peters, 1994: 671). Turning to the UK specifically, part of the problem here is that regional policy which attempts to steer and stimulate investment to particular places has, from the outset, not been designed to foster the sorts of external economies associated with agglomeration proper. Whilst recently regional policy has become synonymous with cluster policy (De Propis and Driffield, 2006: 288) in rhetorical terms, if anything, in its operation since its inception regional policy has become synonymous with the attraction and dispersal of FDI. One key ingredient in the formation of sustainable agglomerations of industry in the UK - in which FDI makes a contribution in terms of positive localised externalities must be a further targeting of assistance. Here the evidence suggests that the incentives associated with regional policy could usefully be concentrated on supporting indigenous enterprise given that: (i) the bulk of regional policy incentives are absorbed by FDI and given that; (ii) FDI contributes its most significant positive external economy effects within existing clusters in which indigenous companies are significant. Correspondingly 
assistamce should be steered away from the support for new FDI-led clusters in which such positive contributions are minimal. Beyond this, as Young, Hood and Peters (1994) indicated is the need also to ensure that national-level education and training and funding for science and technology development reflect and reinforce these choices. Certainly the sort of concentration and concertation of policy and incentives appears to be one of the lessons to be drawn from the experience of the new industry agglomerations that have arisen in developmental states of Northeast Asia.

\begin{abstract}
Alongside the general need for a joined-up approach to coordinating different elements of policy, there remains a need for a greater analytical understanding of the potential points of leverage on MNEs with a view to drawing down benefits is needed. Again, the limited local externalities that attend contingent clustering in industrialising Southeast Asia are all the more sobering given the often quite creative policies of states have not been an unalloyed success. Barely acknowledged, though just as sobering, the powerful economic logic of internalisation that underpins MNE strategy is augmented by an element of complementary political behaviour that, in the western 'competition state' setting has seen MNEs quasi-internalise or capture local externalities - in the form of collective consumption expenditures - where possible. The asymmetrical economic logic toward internalisation over externalisation centred on MNEs' economic activities therefore presents an on-going challenge for local and national governmental bodies to broaden firm-specific concessions to wider business communities.
\end{abstract}


Finally, one indirect product of this paper is to highlight the value of integrating insights from debates regarding FDI and clustering that have tended to remain rather separate within different academic disciplines. It should be clear that critical academic understandings and policy interventions in this sphere can benefit from an interdisciplinary perspective. The asymmetrical bargaining position of MNEs over states can draw on insights from politics and sociology as much as economics. A critical appreciation of the precise benefits to local economies can draw upon the geography and development studies literature as much as the economics and business studies literature. Recent work in economic geography has begun to question not only the extent to which external economies are territorially constrained but also the 'relational' sources of competitive advantage including the international transmission of knowledge and external economies via MNE corporate networks.

\section{ACKNOWLEDGEMENTS}

I would like to thank the British Academy for research funding (SG-39277) that partially enabled the writing of this paper. I would also like to thank, Yong-Sook Lee, two referees and the editors of Regional Studies for comments on a previous draft of this paper and Lyn Ertl for producing the diagrams. Many thanks also to Lai Wa Wong, Henry Yeung and colleagues at the Department of Geography, National University of Singapore for their generous hospitality.

\section{NOTES}


(1) Although FDI is essential to the formation of MNEs, the latter cannot be reduced to the former since the MNE is an organising principle for a series of on-going international connections rather than the one-off transaction that is FDI (Jones, 2005; Wilkins, 2000). MNEs can have considerable economic development impacts on host economies without engaging in FDI through the likes of their relations with suppliers and customers etc. It is precisely these indirect influences that are at play in host economies with the "triangular trade' associated with global production networks which are examined later in the paper.

(2) Moran, Graham and Blomstrom (2005) number this as one of three 'conventional wisdoms' regarding FDI and economic development.

(3) The coherence, especially that of Michael Porter's (1990) version, of the concept of clustering - including that of its geographic scale - is itself open to question (Martin and Sunley, 2003). It is not the intention of this paper to delve into these issues directly. The purpose instead is to question the type and significance of localised externalities associated with the clustering of FDI.

(4) Here several terminological variations exist. Gereffi (1999) refers to global commodity chains, Dicken et al (2001) use the term global production networks, while Felker $(2003,2004)$ uses the term international production networks. 
(5) This may be less likely in the case of some 'buyer-driven' global production networks.

(6) This is not to say that such business strategies are infallible, merely that they are rarely matched by creative or opportunistic strategies on the part of states to fully capture the available externalities. Indeed, as McCann and Mudambi (2005: 1863) note, 'subsidiaries embedded in leading technological centres of competence ... may be sources of potential competitive advantage that actually remain unrealized because of the internal political structure of the MNE'. This, however, is another story and beyond the scope of this paper.

(7) There is a problem of circularity analogous to that regarding the phenomenon of agglomeration and the concept of external economies; does the unequal distribution of FDI, at least in part, account for uneven patterns of economic development globally, or is FDI simply attracted to economically developed areas independent of any economic development contribution.

(8) The concerns of Nunnenkamp and Wade primary are for the prospects of developing countries, though the fundamental insight might also be heeded in the most complacent of 'competition state' nations (Cerny, 1997).

(9) The detailed argument of this paper may be most applicable to 'producer-driven' global production networks and manufacturing-oriented MNEs than to 'buyer-driven' 
global production networks and retail MNEs. However, the general concern of the paper to question the nature and significance of local externalities associated with MNEs - still applies in the case of the latter. Indeed, the problems may be just as intractable though different in nature when one considers the anti-competitive effects of retail MNEs in crowding-out (rather than demonstrating to) rival indigenous firms.

(10) With regard to 'regulatory' issues, MNEs tend to act in industry coalitions. However, to the extent that regulatory issues now constitute part of the package of incentives granted to investors, or have been used directly in 'rules-based' competition among governments, policies in this issue-area arguably have become more susceptible to capture.

(11) Given the dwindling life of FDI projects, the relatively short land use leases granted to overseas investors in the likes of Singapore may actually be a more rational means of effecting both land-use and economic planning objectives than the free land and property markets of western competition states. 


\title{
REFERENCES
}

Agnew, J. (2005) 'Sovereignty regimes: territoriality and state authority in contemporary world politics', Annals of the association of American Geographers 95: 437-461

Aitken, B.J. and Harrison, A.E. (1999) 'Do domestic firms benefit from foreign direct investment? Evidence from Venezuela? American Economic Review 89: 605-618

\begin{abstract}
Alden, J. (1999) The impact of foreign direct investment on job creation: the experience of Wales', pp. 203-220 in Phelps, N.A. and Alden, J. Eds. Foreign Direct Investment and the Global Economy: Corporate and Institutional Dynamics of Global-Localisation. The Stationery Office, Norwich.
\end{abstract}

\begin{abstract}
Altenburg, T. and Meyer-Stamer, (1999) 'How to promote clusters: policy experiences from Latin America', World Development 27: 1693-1713
\end{abstract}
Amin, A., Bradley, D., Gentle, C., Howells, J. and Tomaney,J. (1994) 'Regional incentives and the quality of mobile investment in the less favoured regions of the EC', Progress in Planning 41: 1-112

\begin{abstract}
Amoore, L. (1999) 'Fast but fragile: British restructuring for foreign direct investment in a global era', pp. 16-35 in Garrahan, P. and Ritchie, J. Eds. East Asian Direct Investment in Britain. Frank Cass, London.
\end{abstract}


Bailey, Harte and Sugden, R. (1994) Transnationals and Governments: Recent Policies in Japan, France, German, the United States and Britain. Routledge, London.

Bair, J. and Gereffi, G. (2001) 'Local clusters in global chains: the causes and consequences of export dynamism in Torreon's blue jeans industry', World Development 29 (11): 1885-1903

Bartels, F. (2004) 'The future of intra-regional foreign direct investment patterns in Southeast Asia', pp.80-103 in Freeman, N. and Bartels, F. Eds. The Future of Foreign Investment in Southeast Asia. Routledge, London.

Birkinshaw, J. (1997) 'How subsidiary mandates are won and lost', Journal of International Business Studies 27: 467-496

Birkinshaw, J. (2000) 'Upgrading of industry clusters and foreign investment', International Studies of Management and Organization 30: 93-113

Boddewyn, J.J. (1988) 'Political aspects of MNE theory', Journal of International Business Studies 19: 341-363

Boddewyn, J.J. (1993) 'Political resource and markets in international business: beyond Porter's generic strategies', pp. 83-99 in Rugman and Verbeke, A. Eds. Research in 
Global strategic management: Global Competition - Beyond the Three Generics. JAI Press, London.

Brewer, T.L. (1992) 'An issue-area approach to the analysis of MNE-government relations', Journal of International Business Studies 23: 295-309

Buckley, P. (2004) 'The challenges of the new economy for multinational firms: lessons for Southeast Asia', pp. 15-31 in Freeman, N. and Bartels, F. Eds. The Future of Foreign Investment in Southeast Asia. Routledge, London.

Buckley, P. and Casson, M. (1976) The Future of Multinational Enterprise.

Buckley, P. and Ghauri, P.N. (2004) 'Globalisation, economic geography and the strategy of multinational enterprises', Journal of International Business Studies 35: 81-98

Cantwell, J. (1988) 'The reorganisation of European industries after integration: selected evidence on the role of multinational enterprise activities', in Dunning, J. and Robson, P. Eds. Multinationals and the European Community. Blackwell, Oxford.

Cantwell, J. (1995) 'The globalisation of technology: what remains of the product cycle model', Cambridge Journal of Economics 19: 155-174

Castells, M. (1977) The Urban Question. Arnold, London. 
Cerny, P. (1997) 'Paradoxes of the competition state: the dynamics of political globalization', Government \& Opposition 32: 251-274

Charles, D. and Benneworth, P (1999) 'Plant closure and institutional modernisation: Siemens Microelectronics in the North East', Local Economy 14: 200-213

Coe, N.M. and Lee, Y.S. (2006) 'The strategic localization of transnational retailers: the case of Samsung-Tesco in South Korea', Economic Geography 82: 61-88

Cowling, K. and Sugden, R. (1998) 'The essence of the modern corporation: markets, strategic decision-making and the theory of the firm', The Manchester School 66: 59-86

Dawley, S. (2007) 'Making labour market geographies: volatile "flagship" inward investment and peripheral regions', Environment \& Planning A (forthcoming).

De Propis, L. and Driffield, N. (2006) 'The importance of clusters for spillovers from foreign direct investment and technology sourcing', Cambridge Journal of Economics 30: $277-291$

Dicken, P., Kelly, P., Olds, K., Yeung, H.W.C. (2001) 'Chains and networks, territories and scales: towards an analytical framework for the global economy', Global Networks 1: 89-112 
Driffield, N. (2004) 'Regional policy and spillovers from FDI in the UK', Annals of Regional Science 38: 579-594

Dunning, J. (1979) 'Explaining changing patterns of international production: in defence of the eclectic theory', Oxford Bulletin of Economics and Statistics 41: 269-295

Dunning, J. (1981) 'Explaining the international direct investment position of countries: towards a dynamic or developmental approach', Weltwirtscaftliches Archiv 117: 30-64

Dunning, J. (1997) Alliance Capitalism. Routledge, London.

Van Egeraat, C. and Jacobson, D. (2005) 'Geography of production linkages in the Irish and Scottish microcomputer industry: the role of logistics', Economic Geography 81: 283-304

Encarnation, D. and Wells, L.T. (1985) 'Sovereignty en garde: negotiating with foreign investors', International Organization 39: 47-78

Enright, M. (2000) 'Regional clusters and multinational enterprises: independence, dependence and interdependence', International Studies of Management and Organization 30: 114-138 
Ernst, D. (2001) 'Small firms competing in globalized high-tech industries: the coevolution of domestic and international knowledge linkages in Taiwan's computer industry', pp. 95-130 in Guerrieri, P., Iammarino, S. and Pietrobelli, C. Eds. The Global Challenge to Industrial Districts: Small and Medium-sized Enterprises in Italy and Taiwan. Edward Elgar, Cheltenham.

Ernst, D., Guerrieri, P., Iammarino, S. and Pietrobelli, C. (2001) 'New challenges for industrial clusters and districts: global production networks and technological diffusion', pp. 131-144 in Guerrieri, P., Iammarino, S. and Pietrobelli, C. Eds. The Global Challenge to Industrial Districts: Small and Medium-sized Enterprises in Italy and Taiwan. Edward Elgar, Cheltenham.

Eisinger, P. K. (1988) The Rise of the Entrepreneurial State: State and Local Economic Development Policy in the United States. University of Wisconsin Press, Madison.

Felker, G.B. (2003) 'Southeast Asian industrialisation and the changing global production system', Third World Quarterly 24: 255-282

Felker, G.B. (2004) 'Global production and Southeast Asia's industrialization', pp. 82105 in Jayasuriya, K. Ed. Asian Regional Governance: Crisis and Change. Routledge, London. 
Fisiman, R. and Khanna, T. (2004) 'Facilitating development: the role of business groups', World Development 32: 609-628

Garrett, G. (1998) 'Global markets and national politics: collision course or virtuous circle', International Organization 52: 787-824

Gereffi, G. (1999) 'International trade and industrial upgrading in the apparel commodity chain', Journal of International Economics 48: 37-70

Glasmeier, A. (1988) 'Factors governing the development of high technology industry agglomerations - a tale of three cities', Regional Studies 22: 287-301

Gordon, I. and McCann, P. (2000) 'Industrial clusters: complexes, agglomeration and/or social networks?', Urban Studies 37: 513-538

Graham, E.M. (2003) 'Attracting foreign direct investment to the United States: the Joust between the Federal government and the States', 61-78 in Phelps, N.A. and Raines, P. Eds. The New Competition for Inward Investment: Companies, Institutions and Territorial Development. Edward Elgar, Cheltenham.

Graham, S. and Marvin, S. (2000) Splintering Urbanism. Routledge, London. 
Hodges, M. (1974) Multinational Corporations and National Government: A Case Study of the United Kingdom Experience, 1964-1970. Saxon House, Farnborough.

Hymer, S. (1976) The International Operations of National Firms: A Study of Direct Investment. MIT Press, Cambridge.

Jessop, B. (1999) 'Reflections on globalisation and its (il)logics', pp. 19-38 in Olds, K., Dicken,P., Kelly, P., Kong, L. and Yeung, H.W-C. Eds. Globalisation and the AsiaPacific: Contested Territories. Routledge, London.

Jones, G. (2005) Multinationals and Global Capitalism: From the Nineteenth to the Twenty-first Century. O.U.P., Oxford.

Kindleberger, C. (1969) American Business Abroad. Yale University Press, New Haven.

Kobrin, S. (1986) 'Testing the bargaining hypothesis in the manufacturing sector in developing co8untries', International Organization 41: 609-638

Kobrin, S. (2000) 'Sovereignty@bay: globalization, multinational enterprise, and the international political system', 181-205 in Rugman, A.M. and Brewer, T.L. Eds. The Oxford Handbook of International Business. Oxford University Press, Oxford. 
Lim, S.-H. (2005) 'Foreign investment impact and incentive: a strategic approach to the relationship between the objectives of foreign investment policy and their promotion', International Business Review 14: 61-76

Lindblom, C.E. (1977) Politics and Markets: The World's Political Economic Systems. Basic Books, New York.

Lipsey, F. and Sjoholm, F. (2005) 'The impact of inward FDI on host countries: why such different answers?', pp. 23-43 in Moran, T., Graham, E.M. and Blomstrom, M Eds. Does Foreign Direct Investment Promote Development? Institute for International Economics, Washington DC.

Loewendahl, H. (2000) Bargaining with the Multinationals. Palgrave, Basingstoke.

Lowery, D. (1990) 'The national level roots of the failure of state industrial policy', pp. 191-210 in Yanarella, E. and Green, W. Eds. The Politics of Industrial Recruitment: Japanese Automobile Investment and Economic Development in the American States. Greenwood Press, London.

MacKinnon, D. and Phelps, N.A. (2001) 'Devolution and the territorial politics of foreign direct investment', Political Geography 20: 353-379 
McCann, P. and Mudambi, R. (2004) 'Te location behaviour of the multinational enterprise: some analytical issues', Growth and Change 35: 491-524

McCann, P. and Mudambi, R. (2005) Analytical differences in the economics of geography: the case of the multinational firm', Environment \& Planning A 37: 1857-1876

Mair, A. (1993) 'New growth poles - just-in-time manufacturing and local economic development strategy', Regional Studies, 27 (3): 207-221.

Malmberg, A. and Solvel, O. (2002) 'Does foreign ownership matter? Subsidiary impact on local clusters', pp. 59-78 in Havilla, V. Forsgren, M. and Hakanson, H. Eds. Critical Perspectives on Interntionalisation. Pergamon, London.

Markusen, A. (1996) 'Sticky places in slippery space: a typology of industrial districts', Economic Geography 72: 293-313

Martin, R. and Sunley, P. (2003) 'Deconstructing clusters: chaotic concept or policy panacea?', Journal of Economic Geography 3: 5-35

Massey, D.B. (1984) Spatial Divisions of Labour. MacMillan, London.

Mirza, H. (1986) Multinationals and the Growth of the Singapore Economy. Croom Helm, London. 
Monbiot, G. (2001) Captive State: The Corporate Takeover of Britain. Pan, London.

Mody, A. (2004) 'Is FDI integrating the world economy?', The World Economy 27: $1195-1222$

Moran, T., Graham, E.M. and Blomstrom, M. (2005) 'Introduction and overview', pp.119 in Moran, T., Graham, E.M. and Blomstrom, M Eds. Does Foreign Direct Investment Promote Development? Institute for International Economics, Washington DC.

\begin{abstract}
Munday, M., Peel, M.J. and Taylor, K. (2003) 'The performance of the foreign-owned sector of UK manufacturing: some evidence and implifcations for UK inward investment policy', Fiscal Studies 24: 501-521
\end{abstract}

Murtha, T. and Lenway, S. A. (1994) Country capabilities and the strategic state: how national political institutions affect multinational corporations' strategies', Strategic Management Journal 15: 113-129

NAO (2003) Regional Grants in England: Report by the Comptroller and Auditor General. National Audit Office, HC 702. Stationery Office, London.

Nunnenkamp, P. (2004) 'To what extent can foreign direct investment help achieve international development goals', The World Economy 27: 657-677 
Peck, F. (1996) 'Regional development and the production of space: the role of infrastructure in the attraction of new inward investment', Environment \& Planning A 28: 327-339

Pereira, A. (2003) State Collaboration and Development Strategies in China: the Case of the China-Singapore Suzhou Industrial Park (1992-2002). Routledge, London.

Perry, M. (2005) Business Clusters: An International Perspective. Routledge, London.

Perry, M.and Yeoh, C. (2000) 'Singapore's overseas industrial parks', Regional Studies 34: $199-206$

Peters, E. and Hood, N. (2000) 'Implementing the cluster approach: some lessons from the Scottish experience', International Studies of Management and Organization 30: 6892

Phelps, N. A. (1992) 'External economies, agglomeration and flexible accumulation', Transactions of the Institute of British Geographers 17: 35-46.

Phelps, N.A. (2000) 'The locally embedded multinational and institutional capture', Area 32 (2): 169-178 
Phelps, N.A. (2004a) 'Clusters, dispersion and the spaces in between: for an economic geography of the banal', Urban Studies 41: 971-989

Phelps, N.A. (2004b) 'Archetype for an archipelago? Batam as anti-model and model of industrialisation in reformasi Indonesia', Progress in Development Studies 4 (3): 206-229

Phelps, N.A. and Fuller, C. (2000) 'Multinationals, intracorporate competition and regional development', Economic Geography 76 (3): 224-243

Phelps, N.A. and Fuller, C. (2001) 'Taking care of business: after-care and the state-MNE nexus in Wales', Environment \& Planning C: Government \& Policy 19: 817-832

Phelps, N.A. and Ozawa, T. (2003) 'Contrasts in agglomeration: proto-industrial, industrial and post-industrial forms compared', Progress in Human Geography 27: 583-604

Phelps, N.A. and Tewdwr-Jones, M. (2001) 'Globalisation, regions and the state: exploring the limitations of economic modernisation through inward investment', Urban Studies 38: $1253-1272$

Phelps, N.A., Lovering, J. and Morgan, K. (1998) 'Tying the firm to the region or tying the region to the firm? Early observations on the case of LG in South Wales', European Urban and Regional Studies 5: 119-137 
Phelps, N.A. and Tewdwr-Jones, M. (1998) 'Institutional capacity building in a strategic policy vacuum: the case of the Korean firm LG in South Wales', Environment \& Planning C, Government \& Policy 16 (6): 735-755

Phelps, N.A., Valler, D. and Wood, A. (2005) 'Stealing the skills agenda? Devolution, business and post-16 education and training in Wales', Policy \& Politics 33 (4): 559-579

Porter, M.E. (1990) The Competitive Advantage of Nations. MacMillan, London.

Ramamurti, R. (2001) 'The obsolescing "bargaining model”? MNC-host developing country relations revisited', Journal of International Business Studies 32: 23-39

Rees, G. and Thomas, M. (1994) 'Inward investment, labour market adjustment and skills development: recent experience in South Wales', Local Economy 9: 48-61

Reid, N. and Gattrell, J. 2003) 'Uncertainty, incentives, and the preservation of an industrial icon: the case of Toledo Jeep', pp. 99-118 in Phelps, N.A. and Raines, P. Eds. The new Competition for Inward Investment: Companies, Institutions and Territorial Development. Edward Elgar, Cheltenham.

Rugman, A. and D'Cruz, J. (1997) 'Strategies of multinational enterprises and governments: the theory of the flagship firm', pp. 248-272 in Boyd, G. and Rugman, A. 
Eds. Euro-Pacific Investment and Trade: Strategies and Structural Interdependencies. Edward Elgar, Cheltenham.

Schoenberger, E. (1997) The Cultural Crisis of the Firm. Blackwell, Oxford.

Scott-Kennel, J. and Enderwick, P. (2005) 'FDI and inter-firm linkages: exploring the black box of the investment development path', Transnational Corporations 14: 105-137

Stopford, J. and Strange, S. (1991) Rival States, Rival Firms: Competition for World Market Shares. Cambridge University Press, Cambridge.

Streeten, P. (2001) Globalisation: Threat or Opportunity? Copenhagen Business School Press, Copenhagen.

Tewdwr-Jones, M. and Phelps, N.A. (2000) 'Levelling the uneven playing field: inward investment, inter-regional rivalry and the planning system, Regional Studies 34 (5): 429440

Thomas, K. (2000) Competing for Capital: Europe and North America in a Global Era. Georgetown University Press, Washington DC. 
Thompson, E.R. (2002) 'Clustering of foreign direct investment and enhanced technology transfer: evidence from Hong Kong garment firms in China', World Development 30: 873-889

Tiebout, C.M. (1956) 'A pure theory of local expenditures', Journal of Political Economy 61: $416-424$

United Nations (2001) World Investment Report: Promoting Linkages. United Nations, Geneva.

Vernon, R. (1966) 'International trade, international investment and the product cycle' Quarterly Journal of Economics 80:190-207

Vernon, R. (1971) Sovereignty at Bay: the Multinational Spread of U.S. Enterprises. Basic Books, New York.

Wade, R. (2003) 'What strategies are viable for developing countries today? The world trade organization and the shrinking of "development space", Review of International Political Economy 10: 621-644

Wilkins, M. (2000) 'The history of multinational enterprise', pp. 3-35 in Rugman, A.M. and Brewer, T.L. Eds. The Oxford Handbook of International Business. O.U.P., Oxford. 
Wood, A. (2003) 'The politics of orchestrating inward investment: institutions, policy and practice in the industrial midwest', pp. 79-98 in Phelps, N.A. and Raines, P. Eds. The new Competition for Inward Investment: Companies, Institutions and Territorial Development. Edward Elgar, Cheltenham.

Wrigley, N., Coe, N.M. and Currah, A. (2005) 'Globalizing retail: conceptualizing the distribution-based transnational corporation (TNC)', Progress in Human Geography 29: $437-457$

Yanerella, E. and Green, W. (1990) 'Problems of coalition building in Japanese auto alley: public opposition to the Georgetown/Toyota plant', pp. 153-174 in Yanarella, E. and Green, W. Eds. The Politics of Industrial Recruitment: Japanese Automobile Investment and Economic Development in the American States. Greenwood Press, London.

Yeung, H.W-C. (2000) 'Local politics and foreign ventures in China's transitional economy: the political economy of Singaporean interests in China', Political Geography 19: $809-840$

Yeung, H. W.-C., Liu, W. and Dicken, P. (2006) 'Transnational corporations and network effects of a local manufacturing cluster in mobile telecommunications equipment in China', World Development 34 (3): 520-540. 
Young, S. (2000) 'The multinational corporation: the management challenges of globalization and localization', pp.3-24 in Legewie, J. and Meyer-Ohle, H. Eds. Corporate Strategies for Southeast Asia after the Crisis. Palgrave, Basingstoke.

Hood, N. and Young, S. (1997) 'The United kingdom', pp. 244-282 in Dunning, J.H. Ed. Governments, Globalization and International Business. Oxford University Press, Oxford.

Young, S., Hood, N. and Peters, E. (1994) 'Multinational enterprises and regional economic development', Regional Studies 28: 657-677 
The MNE-Competition state relationship $205 \times 154 \mathrm{~mm}(150 \times 150 \mathrm{DPI})$ 


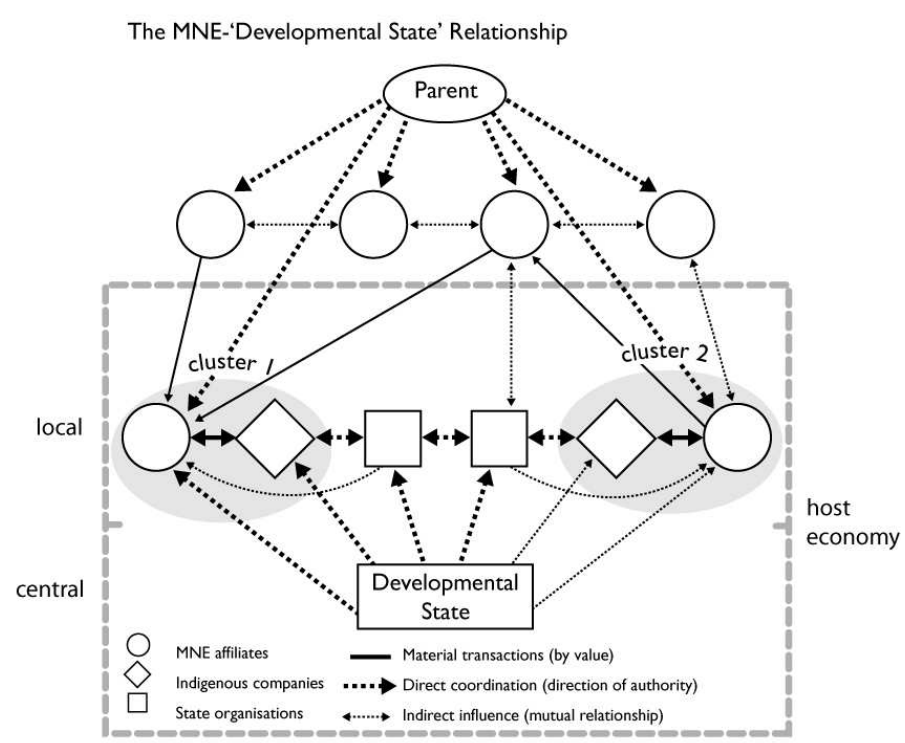

The MNE-developnetal state relationship $210 \times 154 \mathrm{~mm}(150 \times 150 \mathrm{DPI})$ 